\title{
Insurance Sector Analysis in Turkey: An Empirical Study
}

\author{
Hasan Metin, PhD \\ Gjylbehare Llapi, MSc \\ Armend Muja, MSc
}

\begin{abstract}
The purpose of this study is to comprehend the statistical relation between the amount of turnover produced by an employee in insurance companies in Turkey, used as a dependent variable. Whereas, the independent variables are three. The first independent variable is the ratio of number of staff horldiong a Bachelor (BA) over the number of all employees of each insurance company. The second independent varaible is the ratio of the number of sales department crew over number of all employees of each insurance company. The third independent variable is the ratio of number of male salespeople over the number of all sales department of each insurance company. Results indicate that the ratio of the number of male sales department crew over the number of all employees of each insurance company has a negative effect on the average turnover produced by one employee. Moreover, the ratio of number of male salespeople over the number of all sales department of each insurance company is found to have positive effect on the dependent variable. Lastly, the ratio of the number of staff holding a BA degree over the number of all employees of each insurance company has no significant effect on the dependent variable. This study also provides a summary of the basic terms of the concept of insurance and risk. Considering that the profitability is a very crucial issue for the insurance sector as for all other sectors, the profitability ratios of the insurance companies for the last 10 years are provided and analyzed within the study.
\end{abstract}

Keywords: Employment, Insurance, Profitability, Risk, Turnover

\section{Introduction}

\section{THE CONCEPTS OF INSURANCE AND RISK}

Since insurance can be understood as transfer of risk (Muller, 1981), it is the main concept to be covered within the insurance literature. There are different ways of explaining the concept of risk, but the conceptualization of the risk within insurance perspective is very crucial for this study. Mowbray and Blanchard (1961) define risk as "uncertainty" (p.3).

Two famous figures of the sector Nömer and Yunak (2000) state that the term risk is used in three different ways in insurance terminology:

1. "Risk is used with a meaning of danger in the sense of the reason of probable loss"

2. "Risk sometimes means the probability of occurrence of the certain danger. For instance, in this sense, we can state that with the advance alarm system the risk of fire in a factory can be brought down".

3. Risk can refer the object or the person in case of a danger" (p.7).

Risks in general, as the above mentioned scholars explained, have been classified into two main categories: The first category is actual (Pure) risks and speculative risks in the sense of their occurrence. In actual risks, there cannot be any expectation of income for the party that is subject to the risk. Fire and traffic insurances fall on the actual risks. On the other hand, in speculative risks, considering that there is an expectation of profit, the expectation of loss is there, as well. Gambling and stock market investments fall on the speculative risks. The second category to classification of risk is the fundamental risks and particular risks (Nömer and Yunak, 2000). Fundamental risks are the ones that are far away from being individual such as: Catastrophic disasters, war, and inflation. Particular risks are the ones that have individual characteristic such as traffic accident, theft, and so on. 
After clarifying the term risk, various definitions of the term insurance are provided by difference scholars in the following paragraphs.

According to Magee (1947) book that the insurance is defined as follows:

"Insurance is a contract in which the one party in consideration of a price paid in him adequate to the risk, becomes security to the other that he shall not suffer from damage, or prejudice by the happening of the perils specified to certain things which may be exposed to them" (p.43).

Moreover, Magee states that insurance as a business institution has a different meaning. Magee also states that as business institution insurance has been defined as a plan by which large numbers of people associate themselves and transfer, to the shoulders of all, risk that attached to individuals ( $p .43$ ).

According to Williet (1901) insurance is defined as follows:

"We should define insurance, then as the social device for making accumulations to meet the uncertain losses of capital which is carried out through the transfer of the risks of many individuals to one person or to a group of persons. Wherever there is accumulation for uncertain losses or wherever there is transfer of risk, there is one element of insurance; only where these are joined with the combination of risks in a group is the insurance complete" (p.p. 6-7).

Whereas, the Longman dictionary definition of insurance is: "The arrangement with a company in which you pay them money, especially regularly, and they pay the costs if something bad happens, for example if you become ill or your car is damaged".

On the other hand Türkiye Sigorta ve Reasürans Şirketleri Birliği defines insurance as "The transfer of risk, for the group of people who are subject to face the same kind of risk by collecting some amount of money which can only be used for the coverage of the probable risk that might occur" (Türkiye Sigorta ve Reasürans Şirketleri Birliği, 2011).

Two famous figures of the sector Nömer and Yunak (2000) define insurance as: "Economic arrangement of the people that are subject to face that risk by paying some amount of money in order to cover the losses of the people only for that risk" (p.10).

Whereas, Davis, Hood and Stein (1997) provide three different definitions about insurance. The first definition is as follows:

"Insurance is a risk transfer mechanism, whereby the individual or the business enterprise can shift some of the uncertainty of life on the shoulders of others. In return for a known premium, usually a very small amount compared with potential loss, the cost of that can be transferred to the insurer" (p.1).

Second definition is as follows:

"Insurance can be defined from two points of view. First insurance is the protection against financial loss provided by an insurer. Second insurance is a device by means of which the risk of two or more persons of firms are combined through actual or promised contributions to a fund of which claimants are paid. From the viewpoint of the insured insurance is a transfer device. From the viewpoint of the insurer, Insurance is a retention and combination device" (p.1).

Third definition is as follows:

"It is suggested that a contract of insurance is any contract (Merwe, 1970) whereby one party assumes the risk of an uncertain event, which is not within his control, happening at a future time in which the other party has an interest, and under which the party is bound to pay money or provide its equivalent if the uncertain event occurs" (p.1).

The organization of insurance is mainly made up of the 'Insurance company', Insurance Policy' and the 'Insured'.

These terms are defined by Türkiye Sigorta ve Reasürans Şirketleri Birliği (TSRSB)

(In English: Turkish Union Insurance and Reinsurance Companies of Turkey) as follows:

"Insurance company is the party that is authorized to issue insurance policy by the appropriate authorities according to related law and legislation" (Insurance, 2011, para.3). 
"Insured is the party that might face the risk. Insured as a party of the insurance contract (Insurance policy) is authorized the claim the compensation of the loss in case of an occurrence of it" (Insurance, 2011, para. 3).

Insurance policy is "the written and legal proof of the contract between the insurance company and the insured" (Insurance policy, 2011, para.1).

Park (1809) on the other hand states that "Policy is the name given to the instrument by which the contract of indemnity is affected between the insurer and the insured; and it is not like most contracts signed by both parties but only by the insurer..." (Park, 1809, p.1).

Policy mostly contains the definition of both, insurer and the insurance company, explanation about the subject of insurance, coverage, limits, deductions, duration of the policy, premium to be paid, the issuance date of the policy and other responsibilities and duties of the parts of the insurance policy.

\section{THE HISTORY OF INSURANCE}

When we briefly look at the history of insurance we see that the concept itself is very old that it has a history of more than 4000 years. Trennery (1926) states that, "Insurance, develops in connection with Transportation hazards" (Trennery, 1926, p.5).

'So far as extant records furnish evidence, loans of type known during the middle ages by the terms 'bottomry' and 'responlentia' served as the earliest means of in general commercial use to effect of the burden risk" (Trennery, 1926, p.5).

Magee (1947) brings evidence from Babylon and states that:

"Evidence from Babylon by no means conclusive, warrants a presumption that a contract similar to bottomry was known to the merchants of that country and may have originated with their commercial expansion as early as 4000-3000 BC" (Magee, 1947, p.4).

What TSRSB provides basically coheres with what put forward by Magee (1947). According to TSRSB web page:

"The first insurance like activity throughout the history took place in Babylon four thousand years ago. As the trade center of the period equity owners that awarded a loan to the caravan traders, deleted their debt in case of robbery or ransom payment however they charge a little bit more them when they collected their money as the allowance of the risk that they carried. This became a law during Hammurabi. This is the first example of risk sharing in overland transportation" (Date of insurance, 2011, para. 1).

Hindus historically can be considered as the second nation that seemed to be into insurance, as well. According to Walford (1871) "By the Hindus B.C. or earlier intimates that the insurance feature of the evidence from India that the bottomry was practiced contract was understood" (Walford, Layton and Charles, 1871, p. 334).

What TSRSB provides about the insurance or insurance like activities is below:

"During BC 600 Hindus started signing credit agreements which seemed to be insurance like as well. These agreements set examples for the medieval time transport insurance"

(Date of insurance, 2011, para, 2).

According to Trennery (1926) it is well established that the contract is well understood in ancient Greece as early as the fourth century before he Christian era and was used in connection with maritime loans. Later insurance like activities were observed in regions where sea transport was developed.

Duer (1845) gives the same kind of Information in his book as well.

"The same form of loan agreement was adopted by the Romans in their commercial practice and following them by the Maritime nations of Europe during the middle ages". The bottomry contract was widely known and extensively used by the ancient Romans in the ordinary course of business, and the contract is its essential the same contracts as that developed by the Greeks" (Duer, 1845, pp. 20-22). 
Roby (1902) states the following about the same issue "Trajeticia pecunia, the term applied in Roman law to lent on bottomry referred to money lent in mercantile adventure beyond the sea with repayment conditional upon the safe arrival of the security at its destination" (Roby, 1902, p. 75).

Below can be found the TSRSB explanation of the issue:

"Among Greeks, Romans and Carthaginians there were traders who awarded loan on the amount of cargo that the ship had for not fletching the harbor and when the ship fletched the harbor they received their money back and the charged substantial amount of interest. The amount of interest charged was not favored by the church and was prohibited afterwards. Most probably this prohibition caused the merge of idea of receiving premium on the basis of a probable danger, namely the idea of insurance of modern times" (Date of insurance, 2011, para. 3).

The first premium based insurance was observed in Geneva, Venice and Florence AC during 1250s (Date insurance, 2011, para. 4).

"But still insurance of modern times came to the scene in the 14 century. With the changes in the Economic environment trade developed incredibly stating from the 14.century. Italy as the leading figure in Sea Trade felt the need of the insurance and the sea insurance as a concept emerged there" (Date of insurance, 2011, para.4).

The first agreement which is considered to be the first insurance contract dated October 23rd 1347 and secured the cargo of the ship 'Santa Clara' that left Geneva and fronted Majorca. The first insurance company was established in Geneva in 1424.

The first legislation about insurance was enacted was Barcelona Mandate in 1435. Duer (1845) states that: "The first definite ordinances concerning insurance as a specialized contract come from Spain. Moreover, he says that with the ordinances of Barcelona in the $15^{\text {th }}$ century marine insurance became an established institution After Italy's startup it is observed that sea insurance developed in England especially in the 18th century" (Duer, 1845, p. 20).

According to Swiss $\operatorname{Re}(2013)$ world today spends hundreds of billions of USD in risk protection. Economic development, innovation, industrialization would not have prosper to this stage without the private insurance. Only in 2012 there were 4613 billion of USD spent on insurance, worldwide. Private insurance sector increased by acting cautiously to all challenges and changes. Even in the latest economic crisis the insurance sector was less affected than other businesses. Therefore, today life cannot be imagined without risk protection(Swiss Re, 2013, para. 1-2).

Regarding the private insurance, Turkey is moving towards world's trends. According to Firat (2016) Turkey is placed the 63th in the world in respect to insurance density. "The developed countries are on top rows and the per person premium in these countries are 40-50 times than in Turkey. In terms of total premium to GDP rate, Turkeys stays at near last rows" (p.56).

\section{Types of Insurance}

There are different conceptualizations (Bourgin, 1949; Taylor and Murrey, 1982; Stubbart, 2005) and classifications of insurance products in and out of Turkey, insurance will be classified into two main categories in our study:

1. Elementary Insurance (In Turkish: Elementer Sigorta)

2. Life Insurance (In Turkish: Hayat Sigortası)

There are subdivisions under each category and this differentiation is especially very crucial in Turkey. Because insurance companies in Turkey get separate licenses in order to issue policies for Elementary Insurance and Life Insurance.

After providing the names of the types of insurances we will give definitions of the most important ones.

\section{Elementary Insurance}

The main types of Elementary insurance are given below:

Auto Insurance (Kasko-Traffic); Home insurance; Health insurance; Accident, sickness and unemployment insurance; Causality insurance; Earthquake insurance; Flood insurance; Marine insurance; Aviation insurance; Transportation insurance; Liability insurance; Credit insurance; Farm insurance; Third party liability insurance; Employer's liability 
insurance; Product liability insurance; Professional indemnity insurance; Personal accident insurance; Financial loss insurance; Loss of profit insurance and so on.

\section{Life Insurance}

Life insurance category includes:

- $\quad$ Personal Accident Insurance

- $\quad$ Health Insurance

- Life Insurance companies in Turkey can issue the policies below

\section{Retirement Funds}

Some of the insurance types such as Personal accident, Heath insurance and Health voyage insurance have been stated both under elementary and life insurance but the Treasury authorizes companies of both kind to issue the mentioned types of insurance policies.

Heubnert (1947) states that 'Life insurance in its simplest form undertakes to protect the insured's family, creditors or others against pecuniary loss which may be outgrowth of the death of the insured" (pp. 6-10).

All kinds of insurance rely on the same reasoning which is sharing the risk. Life insurance and retirement funds are considered to be another insurance type and the companies get certification through another process in order to issue Life insurance and Retirement fund policies.

\section{Table 1}

\section{Number of Insraunce Companies in Turkey Within Last 10 Years}

\begin{tabular}{llll}
\hline Year & $\begin{array}{l}\text { ELEMENTARY INSURANCE } \\
\text { COMPANIES }\end{array}$ & $\begin{array}{l}\text { LIFE INSURANCE } \\
\text { COMPANIES }\end{array}$ & TOTAL \\
\hline & & & \\
2005 & 53 & 26 & 79 \\
2006 & 47 & 25 & 72 \\
2007 & 54 & 25 & 79 \\
2008 & 55 & 25 & 80 \\
2009 & 59 & 26 & 85 \\
2010 & 57 & 28 & 85 \\
2011 & 59 & 27 & 86 \\
2012 & 58 & 26 & 84 \\
2013 & 60 & 29 & 89 \\
2014 & 63 & 29 & 92 \\
2015 & 62 & 28 & 90 \\
2016 & 62 & 27 & 89 \\
\hline
\end{tabular}

Source: Türkiye Sigorta ve Reasürans Şirketleri Birliği (2011).

Since Insurance sector is very dynamic it is not easy to measure the written premiums of life insurance companies because they keep changing owners, they merge with each other and law about the retirement funds was declared relatively new it is not easy to get meaningful figures. The top 10 elementary companies have not lost their position to be in the first ten in last seven years. Anadolu and Axa exchanged places so did Yapı Kredi and Ergo but they kept their position in the top 10.

Profitability Analysis of Turkish Insurance Companies Between 2006 and 2015 
Profitability analysis for the insurance sector is an area that is very crucial for the sustainability of the insurance companies (Duett and Hershbarger, 1992). In this section profitability analysis of insurance companies is conducted. In order to obtain the ratios, the cumulative financial statements of the insurance companies that are on the web page of TSRSB are used.

The data below were obtained from the cumulative Balance Sheets of Insurance companies which were taken from the web site of TSRSB (Table 4 and Table 5). In Table 6, net profits of the insurance companies are presented. In Table 7, the premiums of insurance companies are given.

\section{Table 2}

\section{Assets of Insurers in Years 2006-2015}

\begin{tabular}{|c|c|c|c|c|}
\hline & & Current Assets & Long Term Assets & Total Assets \\
\hline \multirow[t]{3}{*}{2015} & Elementary & $30,217,522,420$ & $3,510,526,623$ & $33,728,049,043$ \\
\hline & Life & $29,911,860,147$ & $31,934,449,755$ & $61,846,309,901$ \\
\hline & Total & $60,129,382,566$ & $35,444,976,378$ & $95,574,358,944$ \\
\hline \multirow[t]{3}{*}{2014} & Elementary & $25,734,633,630$ & $2,489,243,320$ & $28,223,876,949$ \\
\hline & Life & $25,795,869,499$ & $25,008,408,043$ & $50,804,277,541$ \\
\hline & Total & $51,530,503,129$ & $27,497,651,362$ & $79,028,154,491$ \\
\hline \multirow[t]{3}{*}{2013} & Elementary & $21,833,338,371$ & $2,481,285,431$ & $24,314,623,801$ \\
\hline & Life & $25,067,123,262$ & $13,055,305,103$ & 38.122 .428 .365 \\
\hline & Total & $46,900,461,633$ & $15,536,590,534$ & 62.437.052.167 \\
\hline \multirow[t]{3}{*}{2012} & Elementary & $16,691,464,378$ & $2,262,849,104$ & $18,954,313,482$ \\
\hline & Life & $21,826,383,224$ & $10,067,673,555$ & $31,894,056,779$ \\
\hline & Total & $38,517,847,602$ & $12,330,522,660$ & $50,848,370,262$ \\
\hline \multirow[t]{3}{*}{2011} & Elementary & $14,363,658,534$ & $1,943,964,837$ & $16,307,623,370$ \\
\hline & Life & $16,949,560,377$ & $7,639,031,216$ & $24,588,591,593$ \\
\hline & Total & $31,313,218,911$ & $9,582,996,053$ & $40,896,214,964$ \\
\hline \multirow[t]{3}{*}{2010} & Elementary & $12,377,771,737$ & $1,905,365,172$ & $14,283,136,909$ \\
\hline & Life & $14,644,430,847$ & $6,200,559,284$ & $20,844,990,131$ \\
\hline & Total & $27,022,202,584$ & $8,105,924,456$ & $35,128,127,040$ \\
\hline \multirow[t]{3}{*}{2009} & Elementary & $12,683,217,225$ & $2,260,382,384$ & $14,943,599,609$ \\
\hline & Life & $12,098,308,367$ & $4,212,727,066$ & $16,311,035,433$ \\
\hline & Total & $24,781,525,592$ & $6,473,109,449$ & $31,254,635,042$ \\
\hline \multirow[t]{3}{*}{2008} & Elementary & $10,456,140,977$ & $2,576,411,006$ & $13,032,551,983$ \\
\hline & Life & $10,040,619,764$ & $3,021,121,561$ & $13,061,741,326$ \\
\hline & Total & $20,496,760,742$ & $5,597,532,567$ & $26,094,293,309$ \\
\hline \multirow[t]{3}{*}{2007} & Elementary & $7,984,068,327$ & $3,375,397,394$ & $11,359,465,721$ \\
\hline & Life & $8,151,140,613$ & $2,249,897,483$ & $10,401,038,096$ \\
\hline & Total & $16,135,208,940$ & $5,625,294,877$ & $21,760,503,817$ \\
\hline \multirow[t]{3}{*}{2006} & Elementary & $6,217,402,411$ & $2,838,076,401$ & $9,055,478,812$ \\
\hline & Life & $6,897,926,015$ & $1,322,904,921$ & $8,220,830,936$ \\
\hline & Total & $13,115,328,427$ & $4,160,981,322$ & $17,276,309,749$ \\
\hline
\end{tabular}

Source: Türkiye Sigorta ve Reasürans Şirketleri Birliği (2011). 
When we look at the Table 2 we see that the total assets in general are increasing for the sector from year to year. Elementary insurance companies' total long-term assets figures dropped down till 2010 but starting from 2011 there is a gain increasing pattern in the long-term assets of the elementary insurance companies. Life Insurance companies on the other hand are increasing their both long term and short-term assets every other year.

Table 3 .Liabilities, Owners' Equity of Insurers in Years 2006-2015

\begin{tabular}{|c|c|c|c|c|c|}
\hline & & Liabilities (S.T) & Liabilities(L.T.) & Owners' Equity & Liabilities+QE \\
\hline \multirow[t]{3}{*}{2015} & Elementary & $25,349,262,302$ & $845,667,632$ & $7,533,119,111$ & $33,728,049,045$ \\
\hline & Life & $22,726,985,144$ & $34,255,944,540$ & $4,863,380,218$ & $61,846,309,902$ \\
\hline & Total & $25,349,262,302$ & $35,101,612,172$ & $12,396,499,328$ & $95,574,358,947$ \\
\hline \multirow[t]{3}{*}{2014} & Elementary & $19,405,803,710$ & $706,522,861$ & $8,111,550,381$ & $28,223,876,953$ \\
\hline & Life & $19,100,218,841$ & $27,374,940,148$ & $4,329,118,552$ & $50,804,277,541$ \\
\hline & Total & $38,506,022,552$ & $28,081,463,010$ & $12,440,668,933$ & $79,028,154,494$ \\
\hline \multirow[t]{3}{*}{2013} & Elementary & $16,718,964,897$ & $665,383,960$ & $6,930,274,944$ & $24,314,623,801$ \\
\hline & Life & $18,801,478,387$ & $15,557,269,157$ & $3,763,680,823$ & $38,122,428,367$ \\
\hline & Total & $35,520,443,284$ & $16,222,653,117$ & $10,693,955,767$ & $62,437,052,168$ \\
\hline \multirow[t]{3}{*}{2012} & Elementary & $13,277,604,335$ & $612,711,959$ & $5,063,997,187$ & $18,954,313,481$ \\
\hline & Life & $15,742,037,674$ & $12,636,436,562$ & $3,515,582,546$ & $31,894,056,781$ \\
\hline & Total & $29,019,642,009$ & $13,249,148,520$ & $8,579,579,733$ & $50,848,370,262$ \\
\hline \multirow[t]{3}{*}{2011} & Elementary & $10,606,450,142$ & $547,190,719$ & $5,153,982,512$ & $16,307,623,373$ \\
\hline & Life & $11,445,229,193$ & $10,067,628,495$ & $3,075,733,905$ & $24,588,591,593$ \\
\hline & Total & $22,051,679,335$ & $10,614,819,214$ & $8,229,716,417$ & $40,896,214,966$ \\
\hline \multirow[t]{3}{*}{2010} & Elementary & $8,942,825,463$ & $311,949,895$ & $5,028,361,551$ & $14,283,136,908$ \\
\hline & Life & $9,957,967,168$ & $8,720,314,300$ & $2,166,708,664$ & $20,844,990,131$ \\
\hline & Total & $18,900,792,631$ & $9,032,264,194$ & $7,195,070,215$ & $35,128,127,040$ \\
\hline \multirow[t]{3}{*}{2009} & Elementary & $7,571,493,896$ & $209,828,872$ & $7,162,276,840$ & $14,943,599,609$ \\
\hline & Life & $7,942,297,277$ & $6,709,937,313$ & $1,658,800,843$ & $16,311,035,433$ \\
\hline & Total & $15,513,791,173$ & $6,919,766,185$ & $8,821,077,683$ & $31,254,635,042$ \\
\hline \multirow[t]{3}{*}{2008} & Elementary & $7,194,517,956$ & $223,754,710$ & $5,614,279,317$ & $13,032,551,983$ \\
\hline & Life & 5.877 .443 .130 & 5.776 .885 .351 & 1.407 .412 .845 & $13.061 .741,326$ \\
\hline & Total & $13,071,961,087$ & $6,000,640,061$ & $7,021,692,162$ & $26,094,293.309$ \\
\hline \multirow[t]{3}{*}{2007} & Elementary & $5,464,492,022$ & $199,761,500$ & $5,695,212,199$ & $11,359,465,721$ \\
\hline & Life & $4,750,819,841$ & $4,497,337,821$ & $1,152,880,434$ & $10,401,038,096$ \\
\hline & Total & $10,215,311,863$ & $4,697,099,321$ & $6,848,092,633$ & $21,760,503,817$ \\
\hline \multirow[t]{3}{*}{2006} & Elementary & $4,441,801,045$ & $507,826,919$ & $4,105,850,849$ & $9,055,478,813$ \\
\hline & Life & $3,936,940,796$ & $3,346,661,601$ & $937,228,539$ & $8,220,830,936$ \\
\hline & Total & $8,378,741,841$ & $3,854,488,519$ & $5,043,079,389$ & $17,276,309,749$ \\
\hline
\end{tabular}

Source: Türkiye Sigorta ve Reasürans Şirketleri Birliği (2011). 
The Table 3 provides similar data with respect to Life Insurance companies again. Life Insurance companies' liabilities of each kind are increasing from year to year, but the figures of the Elementary Insurance companies are not that linear. Since short term liabilities are increasing linearly for the Elementary Insurance companies especially the Owner's Equity figure decreased by approximately $25 \%$ in 2010 . But afterwards there is anincreasing trend in the figures of Owner's Equity for the Elementary Insurance companies.

Table 4. The net profit of insurance companies in years 2006-2010

\begin{tabular}{|c|c|c|}
\hline & & Net Profit (TL) \\
\hline 2015 & Elementary & $-576,959,559$ \\
\hline & Life & $826,555,204$ \\
\hline & Total & $249,595,645$ \\
\hline 2014 & Elementary & $729,528,617$ \\
\hline & Life & $658,874,807$ \\
\hline & Total & $1,388,403,424$ \\
\hline 2013 & Elementary & $768,053,434$ \\
\hline & Life & $462,135,572$ \\
\hline & Total & $1,230,189,006$ \\
\hline 2012 & Elementary & $-657,768,672$ \\
\hline & Life & $437,078,501$ \\
\hline & Total & $-220,690,171$ \\
\hline 2011 & Elementary & $-15,429,080$ \\
\hline & Life & $344,549,410$ \\
\hline & Total & $329,120,330$ \\
\hline 2010 & Elementary & -185.534 .008 \\
\hline & Life & 300.278 .771 \\
\hline & Total & 114.744 .762 \\
\hline 2009 & Elementary & $181,810,570$ \\
\hline & Life & $273,694,337$ \\
\hline & Total & $273,694,337$ \\
\hline 2008 & Elementary & $595,954,128$ \\
\hline & Life & $245,268,875$ \\
\hline & Total & $841,223,003$ \\
\hline 2007 & Elementary & $423,741,638$ \\
\hline & Life & $205,796,266$ \\
\hline & Total & $629,537,903$ \\
\hline 2006 & Elementary & $152,766,945$ \\
\hline & Life & $77,731,886$ \\
\hline & Total & $230,498,831$ \\
\hline
\end{tabular}

Source: Türkiye Sigorta ve Reasurans Şirketleri Birliği (2011). 
Table 4 shows that in the first three years the Elementary insurance companies had more profit than the Life Insurance companies but in 2009 the amount of profit that the life insurance companies had exceeded the Elementary Insurance companies and at last in 2010 the Elementary Insurance companies declared loss. After 2010 elementary insurance companies declared loss except 2013 and 2014 while life insurance companies declare profit every year.

\section{Table 5}

The Premiums of insurers in years 2006-2010

\begin{tabular}{lll}
\hline & & Premiums $(\mathrm{TL})$ \\
2015 & Elementary & $27,264,486,899$ \\
& Life & $3,761,410,730$ \\
2014 & Total & $31,025,897,629$ \\
& Elementary & $22,709,549,092$ \\
2013 & Life & $3,280,003,588$ \\
& Total & $25,989,552,680$ \\
2012 & Elementary & $20,834,288,077$ \\
& Life & $3,395,327,657$ \\
2011 & Total & $24,229,615,734$ \\
& Elementary & $17,115,934,207$ \\
20070 & Life & $2,710,826,393$ \\
& Total & $19,826,760,600$ \\
& Elementary & $14,479,407,092$ \\
& Life & $2,685,674,090$ \\
& Total & $17,165,081,182$ \\
& Elementary & 11.948 .144 .242 \\
& Life & 2.181 .250 .027 \\
& Total & 14.129 .394 .269 \\
& Elementary & 10.614 .317 .698 \\
& Life & 1.821 .653 .559 \\
& Total & 12.435 .971 .258 \\
& Elementary & 10.203 .673 .200 \\
& Life & 1.576 .208 .875 \\
& Total & 11.779 .882 .075 \\
& Elementary & 9.597 .468 .685 \\
& Life & 1.412 .198 .649 \\
& Elementary & 11.009 .667 .334 \\
& & 8.068 .170 .649
\end{tabular}




\section{Life \\ Total 9.454 .096 .793}

Source: Türkiye Sigorta ve Reasürans Şirketleri Birliği (2011).

Table 5 shows that there is a very linear pattern with respect to the turnovers of both Elementary and Life Insurance Companies. Every other year the turnover is increasing with approximately similar ratios.

\section{Profitability Ratios}

Based on the financial statements provided in the previous section, three profitability ratios of the insurance companies between 2006 and 2015 are calculated. These profitability ratios are retun on Sales (ROS), Return on Assets (ROA) and Return on Equity (ROE). The results are provided in Table 6.

\section{Table 6}

Profitability ratios of insurance companies in years 2006-2010

\begin{tabular}{|c|c|c|c|c|}
\hline & & $\mathrm{ROA}$ & ROE & ROS \\
\hline \multirow[t]{2}{*}{2015} & Elementary & $-1,71 \%$ & $-7,66 \%$ & $-2,12 \%$ \\
\hline & Life & $1,34 \%$ & $17,00 \%$ & $21,97 \%$ \\
\hline \multirow[t]{2}{*}{2014} & Elementary & $2,58 \%$ & $8,99 \%$ & $3,21 \%$ \\
\hline & Life & $1,30 \%$ & $15,22 \%$ & $20,09 \%$ \\
\hline \multirow[t]{2}{*}{2013} & Elementary & $2,67 \%$ & $11,08 \%$ & $3,69 \%$ \\
\hline & Life & $1,21 \%$ & $12,28 \%$ & $13,61 \%$ \\
\hline \multirow[t]{2}{*}{2012} & Elementary & $-3,42 \%$ & $-12,99 \%$ & $-3,84 \%$ \\
\hline & Life & $1,37 \%$ & $12,43 \%$ & $16,12 \%$ \\
\hline \multirow[t]{2}{*}{2011} & Elementary & $-0,09 \%$ & $-0,30 \%$ & $-0,11 \%$ \\
\hline & Life & $1,40 \%$ & $11,20 \%$ & $12,83 \%$ \\
\hline \multirow[t]{2}{*}{2010} & Elementary & $-1,30 \%$ & $-3,69 \%$ & $-1,55 \%$ \\
\hline & Life & $1,44 \%$ & $13,86 \%$ & $13,77 \%$ \\
\hline \multirow[t]{2}{*}{2009} & Elementary & $1,22 \%$ & $2,54 \%$ & $1,71 \%$ \\
\hline & Life & $1,68 \%$ & $16,50 \%$ & $15,02 \%$ \\
\hline \multirow[t]{2}{*}{2008} & Elementary & $4,57 \%$ & $10,61 \%$ & $5,84 \%$ \\
\hline & Life & $1,88 \%$ & $17,43 \%$ & $15,56 \%$ \\
\hline \multirow[t]{2}{*}{2007} & Elementary & $3,73 \%$ & $7,44 \%$ & $4,42 \%$ \\
\hline & Life & $1,98 \%$ & $17,85 \%$ & $14,57 \%$ \\
\hline \multirow[t]{2}{*}{2006} & Elementary & $1,69 \%$ & $3,72 \%$ & $1,89 \%$ \\
\hline & Life & $0,95 \%$ & $8,29 \%$ & $5,61 \%$ \\
\hline
\end{tabular}

Source: Türkiye Sigorta ve Reasürans Şirketleri Birliği (2011).

Table 6 shows that the profitability ratios of Life Insurance companies are higher than elementary Insurance Companies in general. In 2010, profitability ratios of the Elementary Insurance companies are all negative due to the declaration of cumulative loss of the sector. In 2009, the profitability ratios are all positive. Life Insurance companies, on the other hand, have positive ratios in 2010. Even if the ratios are positive for Life Insurance companies in 2010, all three ratios are less than 2009's figures. In 2009, we figure a noticeable decrease in the profitability ratios of the Elementary Insurance companies compared to 2008 ratios. The ROA of 2008 for elementary insurance companies was 4,57\% in 2008 and $1,22 \%$ 
in 2009. ROE of Elementary insurance companies decreased from $10,61 \%$ to $2,54 \%$ and ROS decreased from $5,84 \%$ to $1,71 \%$. There are very obvious decreases. The figures of the Life Insurance companies from 2008 to 2009 have changed very slightly that the ratios of the changes are less than $10 \%$.

In 2008, a positive change is observed when compared with 2007 figures for Elementary Insurance Companies. ROA increased from 3, 73\% to 4, 57\%; ROE increased from 7, $44 \%$ to $10,61 \%$ and ROS increased from $4,42 \%$ to $5,84 \%$ for Elementary Insurance Companies. The ratios for Life Insurance companies on the other hand decreased very slightly that, it is possible to say that there is no difference from 2007 to 2008 for Life Insurance Companies with respect to their profitability ratios. In 2007, the ROA and ROE figures of both Elementary and Life Insurance companies increased more than $100 \%$ when compared with 2006 figures. But the ROS figures increased even more. Life Insurance Companies' 2007 ROS figure is approximately three times more than 2006 ROS figure. Elementary Insurance Companies' ROS figure again increased from $1,89 \%$ to $42 \%$.

Starting from 2011 Elemantary Insurance Companies ROAs ROEs and ROSs have negative values except 2013 and 2014 while Life Insurance companies had always positive figures with repect to ROAs ROEs and ROSs.

\section{METHODOLOGY}

Linear regression has been utilized in order to determine the effect of the independent variables of the study (the ratio of number of BA degree holding staff over number of all employees of each insurance company, the ratio of the number of sales department crew over number of all employees of each insurance company, the ratio of number of male salespeople over member of all sales department of each insurance company) on the dependent variable (the amount of turnover produced by an employee in insurance companies in Turkey). Statistical Package for the Social Sciences (SPSS) has been used for the analysis. The data were available at the web-page TSRSB. The hypotheses of the study are as follows:

Hypothesis 1: The ratio of number of BA degree holding staff over number of all employees of each insurance company affects the amount of turnover produced by an employee in insurance companies.

Hypothesis 2: The ratio of the number of sales department crew over number of all employees of each insurance company affects the amount of turnover produced by an employee in insurance companies.

Hypothesis 3: The ratio of number of male salespeople over member of all sales department of each insurance company effects the amount of turnover produced by an employee in insurance companies.

The dependent variable turnover is considered as the average amount of premium that one employer can produce. It is calculated by dividing the total amount of turnover by the number of people working within the insurance company. The other figures meaning the independent variables are all percentages. The turnover figures that the study has are mostly six or seven digit numbers that the significance figures of the variables are not in the acceptable interval. That is why the dependent variable has been converted the logarithmic function that the analysis would give more reliable results. Below table 5 presents the coefficients and the significance rates of the variables.

\begin{tabular}{|c|c|c|c|c|c|}
\hline & \multicolumn{2}{|c|}{ Unstandardized Coefficients } & $\begin{array}{l}\text { Standardized } \\
\text { Coefficients }\end{array}$ & $\mathrm{T}$ & Sig. \\
\hline & B & Std. Error & Beta & & \\
\hline (Constant) & 13,377 & 1.088 & & 12,295 & 0.000 \\
\hline $\begin{array}{l}\text { Univ Total } \\
\text { Males Total }\end{array}$ & $\begin{array}{l}0,012 \\
-0.079\end{array}$ & $\begin{array}{l}0.017 \\
0.022\end{array}$ & $\begin{array}{l}0.114 \\
-0.663\end{array}$ & $\begin{array}{l}0,725 \\
-3.522\end{array}$ & $\begin{array}{l}0.474 \\
0.001\end{array}$ \\
\hline Males sales sales & 0,016 & 0,008 & 0,393 & 2,115 & 0,043 \\
\hline
\end{tabular}

As it can easily be seen above the significance rate of the ratio of number of BA degree holding staff over number of all employees of each insurance company is above the acceptable rate that it will be converted to a logarithmic function in order to eliminate the significance problem.

Table 5b Coefficients 


\begin{tabular}{|c|c|c|c|c|c|}
\hline & \multicolumn{2}{|c|}{ Unstandardized Coefficients } & \multirow{2}{*}{$\begin{array}{l}\begin{array}{l}\text { Standardized } \\
\text { Coefficients }\end{array} \\
\text { Beta }\end{array}$} & \multirow[t]{2}{*}{ T } & \multirow[t]{2}{*}{ Sig. } \\
\hline & B & Std. Error & & & \\
\hline (Constant) & 11,518 & 1.088 & & 12,295 & 0.000 \\
\hline Ln (univ) Total & 0,632 & 1,001 & 0.100 & 0,631 & 0.532 \\
\hline Males Total & -0.078 & 0.022 & -0.658 & $\begin{array}{l}-3.492 \\
-\end{array}$ & 0.001 \\
\hline Males sales sales & 0,016 & 0,008 & 0,392 & 2,096 & 0,044 \\
\hline
\end{tabular}

Even if the ratio of number of BA degree holding staff over number of all employees of each insurance company is converted to a logarithmic function, the significant rate is still not acceptable. Eliminating it from the equation seems to be the best solution.

\begin{tabular}{llllll}
\hline Table 5c Coefficients & \multicolumn{7}{l}{} \\
\hline & Unstandardized Coefficients & $\begin{array}{l}\text { Standardized } \\
\text { Coefficients }\end{array}$ & T & Sig. \\
\hline & B & Std. Error & Beta & & \\
\hline (Constant) & 14,126 & 0.339 & & 41,664 & 0.000 \\
Males Total & -0.075 & 0.021 & -0.629 & -3.476 & 0.001 \\
Males sales sales & 0,015 & 0,007 & 0,367 & 2,026 & 0,051 \\
\hline
\end{tabular}

Eliminating the ratio of number of BA degree holding staff over number of all employees of each insurance company overcomes the above problem that the significance ratios are at the acceptable level at the 90 percent confidence level.

\begin{tabular}{|c|c|c|c|c|c|}
\hline $\begin{array}{l}\text { Table } 6 \\
\text { ANOVA }\end{array}$ & $\begin{array}{l}\text { Sum of } \\
\text { Squares }\end{array}$ & df & $\begin{array}{l}\text { Mean } \\
\text { Square }\end{array}$ & $F$ & Sig. \\
\hline Regression & 10,270 & 2 & \multirow{2}{*}{$\begin{array}{l}5,135 \\
0.849\end{array}$} & \multirow[t]{2}{*}{6,048} & \multirow[t]{2}{*}{$0.006 \mathrm{~b}$} \\
\hline $\begin{array}{l}\text { Residual } \\
\text { Total }\end{array}$ & $\begin{array}{c}27,168 \\
37.438\end{array}$ & $\begin{array}{l}32 \\
34\end{array}$ & & & \\
\hline
\end{tabular}

Table 7

Model

Summary

\begin{tabular}{lllll}
\hline \multicolumn{2}{c}{ Summary } & & & \\
\hline & & & Std. & \\
& $\mathrm{R}$ & $\mathrm{R}$ & Adjusted & Error of \\
$\mathrm{R}$ & Square & Square & Estimate & Wurbin- \\
\hline 0.524 & 0.274 & 0.229 & 0.92141 & 1.471 \\
\hline
\end{tabular}

ANOVA table, table 6, presents that our model does not have any significance problems. Moreover, the summary of the model is also given in Table 7.

Therefore, findings of the linear regression indicate the following:

1- $\quad$ The ratio of number of BA degree holding staff over number of all employees of each insurance company has no significant effect on the turnover.

2- $\quad$ The ratio of the number of sales department crew over number of all employees of each insurance company negatively affect the amount of turnover produced by an employee in insurance companies 
3- $\quad$ The ratio of number of male salespeople over member of all sales department of each insurance company positively effects the amount of turnover produced by an employee in insurance companies.

The regression function is $\operatorname{Ln}$ (Turnover) $=14,126-0.075$ (male sales total) $+0,015$ (male sales sales)

The equation above means 1 standart unit increase in the ratio of the number of sales department crew over number of all employees of each insurance company causes 0.075 standart unit decrease in Ln of the Turnover, and 1 standart unit increase in the ratio of number of male salespeople over member of all sales department causes 0,015 standart unit increase in Ln of the Turnover.

\section{CONCLUSION}

\section{Discussion}

This study provides a summary of the basic terms of the concept of insurance and risk from different resources and scholars. Afterwards, historical background of the sector has been provided with the improvement of the sector in Turkey. The names of the existing companies, the numbers of the past companies have been provided as well.

The study also provides the profitability ratios of both elementary and life insurance companies from 2006 to 2015 . The life insurance companies in general have positive figures with respect to their profitability ratios. Elementary Insurance companies, on the other hand, do not have a stable profit or loss but in the last five years except 2013 and 2014 elementary insurance companies declared losses.

In the regression analysis, the equation among the mentioned variables above has been determined and it is concluded that employing university graduates does not have an effect on the turnover statistically. Having a high rate male staff on the sales department on the other hand seems to have a positive effect on the turnover, while having a high rate male staff in total has a negative effect on turnover.

\section{Managerial Implications}

As mentioned in the discussion part, employing males in the sales department in insurance sector seems to have a positive effect on the turnover, but the ratio of the males over number of all employees of each insurance company negatively affect the turnover that it seems that the female ratio in the other departments should be higher than male ratio.

\section{Limitations}

The limitations of the study would be the low $R$ squared score.

\section{Future Research Recommendations}

Future Researches might focus on female employement directly.

\section{REFERENCES}

[1] Blanchard, R. (1940). The Buyer's Viewpoint on Life Insurance: Discussion. Journal of the American Association of University Teachers of Insurance, 7(1), 59-60. doi: 10.2307/250059.

[2] Bourgin, C. (1949). Types of Insurance Protection. Journal American Water Works Association, 41(10), 907-910. Retrieved from http://www.jstor.org/stable/41235084.

[3] Browne, M., \& Kim, K. (1993). An international analysis of life insurance demand. The Journal of Risk and Insurance, 60(4), 616-634. doi:10.2307/253382.

[4] Davis, M. \& Hood, J. \& Stein, B. (1997). Insurance non-marine: An introduction. London: Witherby \& Co. Ltd.

[5] Denenberg, H. (1963). The Legal Definition of Insurance: Insurance Principles in Practice. The Journal of Insurance, 30(3), 319-343. doi:10.2307/250245.

[6] Duer, J. (1845). The law and Practice of Marine Insurance. New York: John S Voorhies Vol.1.

[7] Duett, E., \& Hershbarger, R. (1992). Profitability of title insurance companies. Journal of Insurance Issues, 15(1), $13-30$. Retrieved from http://www.jstor.org/stable/41946341. 
[8] Firat, A. (2016). Insurance in Turkey and main problems of the sector. BISKA, Bilisim Technology, CMMA 1, No. 2, 50-57 (2016) Retrieved form: http://dergipark.gov.tr/download/article-file/276139

[9] H. Sadhak. (2006). Life insurance and the macro economy: Indian experience. Economic and Political Weekly, 41(11), 1108-1112. Retrieved from http://www.jstor.org/stable/4417977.

[10] Heubner, S.S. (1947). The economics of life insurance. New York: D Appleton \& Co.

[11] Koralt, M. Kazgan, H. \& Soyak, A. İstanbul. (1998). Cumhuriyetin 75 yıllık Sigortacısı Koç Alianz İstanbul: Koç Alianz Yayınları.

[12] Magee, H. J. (1947). General Insurance. Chicago: Richard D Irwin, Inc.

[13] McQuaid, R., \& Lindsay, C. (2005). The concept of employability. Urban Studies, 42(2), 197-219. Retrieved from http://www.jstor.org/stable/43100695.

[14] Mowbray, H. A. \& Blanchard, H.R. (1961). Insurance, its theory and practice in the United States. New York: McGraw-HILL Book Company, Inc.

[15] Müller, W. (1981). Theoretical concepts of insurance production. The Geneva Papers on Risk and Insurance, 6(21), 63-83. Retrieved from http://www.jstor.org/stable/41950020.

[16] Nömer, C. \& Yunak, H. (2000). Sigortanın Genel Prensipleri. İstanbul: Ceyma Matbaclık.

[17] Park, A.A. (1809). System of the Law of the Marine Insurance: With three chapters on insurance on lives and on insurance against fire. Dublin: James Co Ltd.

[18] Roby, H.J. (1902). Roman private law. Cambridge. University Press, Volume.2.

[19] Stubbart, J. (2005). What type of insurance do we need? Opflow, 31(8), 6-8. Retrieved from http://www.jstor.org/stable/43277681

[20] Swiss Re. The history of insurance. (2013). Swiss Re. Retrieved from: (http://jpkc.fudan.edu.cn/picture/article/250/46/e1/34c56e6d4aba8043d10610537157/839bb594-7aa1-406a-9db6d2ba011b8375.pdf

[21] Taylor, R. \& Murrey, J. (1982). Insurance buyers perceived risk and profiles. The Journal of Insurance Issues and Practices, 5(2), 25-43. Retrieved from http://www.jstor.org/stable/41943111

[22] Theil, M. (2000). To insure or not to insure? Considerations on irrational strategies to take out insurance. The Geneva Papers on Risk and Insurance. Issues and Practice, 25(2), 288-295. Retrieved from http://www.jstor.org/stable/41952531

[23] Toprak, Z. (2010). Geçmişten geleceğe Anadolu sigorta, Türkiyenin sigortası İstanbul: İ̧̧ Bankası Yayınları.

[24] Trennery, C.F.Y. (1926). Origin and the early history of insurance, including the contract of bottomry. London: P.S.King \& Son Ltd.

[25] Türkiye Sigorta ve Reasürans Şirketleri Birliği (TSRSB). (May and June 2011). Retrieved from: http://www.tsrsb.org.

[26] Türkiye Sigorta ve Reasürans Şirketleri Birliği (TSRSB). Insurance policy. (2011). Retrieved from: https://www.tsb.org.tr/sigorta-tanimlari.aspx?pagelD=648

[27] Türkiye Sigorta ve Reasürans Şirketleri Birliği (TSRSB). Insurance. (2011). Retrieved from: https://www.tsb.org.tr/sigortatanimlari.aspx?pagelD $=648$

[28] Türkiye Sigorta ve Reasürans Şirketleri Birliği (TSRSB). Date of insurance. (2011). Retrieved from: https://www.tsb.org.tr/sigortanin-tarihi.aspx?pagelD=438

[29] Van der Merwe, S. (1970). The concept of insurance and the insurance contract. The Comparative and International Law Journal of Southern Africa, 3(2), 149-167. Retrieved from http://www.jstor.org/stable/23240782.

[30] Walford, C. (1871-78). Insurance Cyclopedia London: Charles and Edwin Layton, Vol.1.

[31] Williet, A.H. (1901). The economic theory of risk and insurance. New York: Columbia University Press.

[32] Wittekind, A., Raeder, S. \& Grote, G. (2010). A longitudinal study of determinants of perceived employability. Journal of Organizational Behavior, 31(4), 566-586. Retrieved from http://www.jstor.org/stable/41683929. 